\title{
An Ecological Approach to Regulatory Studies?
}

\author{
CHRISTINE PARKER AND FIONA HAINES
}

\begin{abstract}
Regulatory studies has been mainly occupied with addressing the social and economic crises of contemporary capitalism largely through instrumentally and responsively rational approaches. This paper asks how regulatory studies scholarship can better respond to the ecological crisis now facing our world and our governance systems alongside social and economic crises. Instrumentally rational regulatory approaches see buman ecological impact as an externality or market failure. Socio legal approaches to regulatory studies challenged and developed the instrumentally rational approach by emphasizing the need to attend to the social and political aspects of regulation using a responsively rational approach. This paper proposes the need for a third big shift towards an ecologically rational approach to regulatory studies that better comprehends our embeddedness and interconnectedness within ecological systems. Our suggested approach is not alone in arguing for strong limits to be placed on ecologically damaging activity but an ecologically rational approach also calls for an understanding of how multiple, diverse ways of sustainable being can intersect with and challenge current regulatory regimes dominated by an instrumentally rational approach.
\end{abstract}

This paper has been published as: Fiona Haines and Christine Parker, "An ecological approach to regulatory studies?". Journal of Law and Society, 2018, 45(1), 136-155, special issue edited by Bronwen Morgan and Amelia Thorpe, 'Law for a new economy: enterprise, sharing, regulation'. The published version is available at https://onlinelibrary.wiley.com/doi/abs/10.1111/jols.12083

Professor Christine Parker, Melbourne Law School, University of Melbourne, VIC 3010, Australia. Email: christine.parker@unimelb.edu.au

Professor Fiona Haines, School of Social and Political Sciences, Faculty of Arts, University of Melbourne, VIC 3010, Australia.Email:f.haines@unimelb.edu.au 
We are grateful for comments on an earlier version to Bronwen Morgan and the other participants at the workshop "Between Activism and Enterprise: The Role of Law in Redefining Growth and Prosperity in the New Economy" in August 2016 at University of New South Wales. 


\section{INTRODUCTION}

Regulatory studies has to date been mainly occupied with addressing the global social and economic systems crises of contemporary capitalism. ${ }^{1}$ Yet capitalism and indeed human development now face the existential challenge of "abrupt global environmental change" due to anthropogenic pressure. ${ }^{2}$ The emerging discipline of earth systems science aims to define a "safe operating space for human societies to develop and thrive, based on our evolving understanding of the functioning and resilience of the Earth system"3 Taking earth systems seriously means recognising that economics, capitalism and all human governance mechanism can only continue to operate within the ecologically safe zone for humans. While environmental regulation and governance in the past might have defined pollution and use limits for specific local waterways or airsheds and sought to limit environmental impact at a local, regional or even national level, it is now clear that human activity is causing environmental change at a continental and planetary level. Earth system scientists suggest that we have already transgressed three of nine "planetary boundaries" in which humanity can safely operate - climate change, biodiversity loss and biogeochemical flows (i.e. nitrogen due to fertiliser use) - meaning that global, catastrophic environmental change is imminent and may trigger further global environmental change in the other boundaries. ${ }^{4}$ In a very real sense a "defiant earth" may take away human life support systems. ${ }^{5}$

Regulatory governance systems urgently need to adapt to ensure that humanity - including business and government - operate within ecological limits at a planetary scale whilst also still responding to social and economic tensions and crises. Political scientists, lawyers and sociologists of science are all developing responses to this challenge with notions such as ecological democracy, ${ }^{6}$ earth jurisprudence, ${ }^{7}$ the sustainocene, ${ }^{8}$ ecolaw, ${ }^{9}$ the new climatic regime ${ }^{10}$ and many others all proposed as radically new ways of thinking about how to govern well within planetary boundaries. This paper asks how the scholarly and policy field of regulatory studies should change to address this challenge and embrace what we call "ecologically rational regulation" of businesses and capitalism itself.

In the first part of this paper we draw on Levi-Faur's notion of "regulatory capitalism", ${ }^{11}$ the idea that capitalism and regulatory governance are interdependent and interrelated, to assess how well current understandings of regulation address the need to stay within planetary boundaries. We suggest that the

\footnotetext{
${ }^{1}$ Fiona Haines, The Paradox of Regulation: What Regulation Can Achieve and What It Cannot (Cheltenham: Edward Elgar, 2011).

2 Johan Rockström et al., "Planetary Boundaries: Exploring the Safe Operating Space for Humanity," Ecology and society 14, no. 2 (2009).; Will Steffen et al., "Planetary Boundaries: Guiding Human Development on a Changing Planet," Science 347, no. 6223 (2015).

3 Will Steffen et al., "Planetary Boundaries: Guiding Human Development on a Changing Planet," Science 347, no. 6223 (2015). p1259855-1

${ }^{4}$ Id. See also the Millennium Ecosystem Assessment, Ecosystems and Human Well-Being: Synthesis (Washington, DC: Island Press, 2005) (prepared for the UN in 2000 and finding 15 out of 24 major systems in decline).

${ }^{5}$ See Clive Hamilton, Defiant Earth: The Fate of Humans in the Anthropocene (Crows Nest, NSW: Allen and Unwin, 2017).

${ }^{6}$ John S Dryzek, Deliberative Democracy and Beyond: Liberals, Critics, Contestations (Oxford University Press 2000).; John Keane, "The Greening of Democratic Politics " The Conversation (2013).

${ }^{7}$ Cormac Cullinan, Wild Law: A Manifesto for Earth Justice (Green Books: Totnes, UK, 2011), Michelle Maloney, "The Role of Regulation in Reducing Consumption by Individuals and Households in Industrialised Nations" (Griffith University, 2014).

8 Thomas Faunce, "Towards a Global Solar Fuels Project-Artificial Photosynthesis and the Transition from Anthropocene to Sustainocene," Procedia Engineering 49 (2012).

${ }^{9}$ Fritjof Capra and Ugo Mattei, The Ecology of Law: Toward a Legal System in Tune with Nature and Community (Oakland, California: Berrett-Koehler Publishers, 2015).

${ }^{10}$ Bruno Latour, Facing Gaia: Eight Lectures on the New Climatic Regime (Polity Press, 2017).

${ }^{11}$ David Levi-Faur, "Regulatory Capitalism," in Regulatory Theory: Foundations and Applications, ed. Peter Drahos (The Australian National University, Canberra, Australia: ANU Press, 2017).
} 
dominant policy approach, instrumentally rational regulation, sees capitalism's impact on the natural world as an "externality" or market failure. Regulatory tools of a variety of kinds are then proposed to address environmental harms one issue at a time, with care to simultaneously promote competition and support entrepreneurialism. The most prominent alternative is responsively rational regulation, which emphasizes the interconnected nature of social, political and economic challenges for capitalism and the need for iterated challenge, consultation and development of regulatory policy and compliance by a plurality of networked public and private actors. Here, environmental responsibility is promoted as taking place through consultation with and response to environmental NGOs, actors who might be seen to stand for and represent trees, rivers, environments and animals. ${ }^{12}$ It recognises, indeed hopes, virtuous and rapid change can occur when networked actors recognise that they share the burden of risk or community of fate. ${ }^{13}$

In the second part of the paper, we argue for a third shift in regulatory studies scholarship and practice towards a fuller comprehension of our embeddedness as a human species (with all our business, market, legal, political and social structures) inside ecological systems. ${ }^{14}$ Within earth systems we humans - and our social and economic systems - are inextricably interconnected with and interdependent on diversity, dynamism and generative capacity of the "earth community" 15 - including rocks, trees, rivers and bees to create the energy, water, food and materials we use. An ecologically rational approach to regulation would accept and build on "flashes"16 of ecologically rational insight from both the other two approaches. Yet much more is needed in recognition of the fact that human flourishing is only possible within ecological (as well as social, economic, social and political) systems. We suggest some ways instrumentally rational and responsively rational regulation can help comprehend this challenge and propose some principles for action and questions for further research on ecologically rational regulation.

First, an ecologically rational approach to regulation must learn to listen to ecological systems that sustain life and set boundaries to eliminate behaviour inimical to the integrity of life support systems. This might include radically interventionist "top down" measures such as the establishment of legal and regulatory norms against ecocide including the criminalisation of further emissions of greenhouse gases into the atmosphere by fossil fuels companies. ${ }^{17}$

The second challenge for ecologically rational regulatory studies is to understand how an ecologically rational approach can be supported from the 'ground up'. There are already many different ways in which ecological sustainability is being pursued with a plethora of initiatives in food, ${ }^{18}$ alternative economic systems, ${ }^{19}$ and circular production. ${ }^{20}$ How do current regulatory regimes support and inhibit these specific

\footnotetext{
12 See Christoper Stone, Should Trees Have Standing? Law, Morality and the Environment, Third edition ed. (Oxford: Oxford University Press, 2010).

13 Peter Drahos, "Regulating Capitalism's Processes of Destruction," in Regulatory Theory: Foundations and Applications, ed. Peter Drahos (Canberra, Australia: ANU Press, 2017) at 776. See J. Braithwaite and P. Drahos, Global Business Regulation (Cambridge: Cambridge University Press, 2000); Joe Rees, Hostages of Each Other: The Transformation of Nuclear Safety since Three Mile Island (Chicago: University of Chicago Press, 1994).

${ }^{14}$ See also Maloney, "The Role of Regulation in Reducing Consumption by Individuals and Households in Industrialised Nations".

15 To use Thomas Berry's memorable phrase: see Mary Evelyn Tucker and John Grim, Thomas Berry: Selected Writings on the Earth Community (Maryknoll, NY: Orbis Books, 2015).

${ }^{16}$ Cullinan, Wild Law: A Manifesto for Earth Justice at 31; see also Maloney, "The Role of Regulation in Reducing Consumption by Individuals and Households in Industrialised Nations".

${ }^{17}$ Fiona Haines, Corporate Regulation: Beyond Punish or Persuade' (Oxford: Clarendon Press, 1997).; Rob. White and Ronald C. Kramer, "Critical Criminology and the Struggle against Climate Change Ecocide," Critical Criminology 23 (2015).

18 ibid. 35-37.

19 See JK Gibson-Graham, Jenny Cameron and Stephen Healy, Take Back the Economy, Environmental Education Research (Minneapolis: University of Minnesota Press, 2013).
} 
initiatives that have risen to chart a sustainable future? Ecologically rational regulatory studies would ask firstly, whether and how these initiatives challenge and transform the dominance of entrenched interests, production systems and financial flows that are inherently ecologically unsustainable and what role regulation plays in mediating conflict between the sustainable and the unsustainable. But various ecologically sustainable future initiatives may also be in competition with each other. Therefore ecologically rational regulatory studies should inquire into how contestation between various ecological initiatives are themselves mediated through regulation. We argue that co-existence of and contestation between different visions of sustainable futures is desirable and indeed generative. Taking a leaf from ecosystems themselves, we suggest that ecological regulation should not assume that sustainability is monocultural, but rather the challenge for ecological regulation is in supporting and sustaining a multiplicity of diverse initiatives that interact with one another within planetary boundaries. We therefore conclude with some challenges and an agenda for further investigation of ecologically rational regulation.

\section{ANALYSING THE CHALLENGES FOR ECOLOGICAL REGULATION: THE INSTRUMENTALLY AND RESPONSIVELY RATIONAL APPROACHES TO REGULATORY STUDIES}

\section{The dominant conception: the instrumentally rational approach}

David Levi-Faur has observed that "capitalism is a regulatory institution - one that is being constituted, shaped, constrained and expanded as a historically woven patchwork of regulatory institutions, strategies and functions." 21 On the one hand, as Levi-Faur observes, "regulation made, nurtured and constrained the capitalist system". ${ }^{22}$ That is regulation creates and legitimates capitalist economies through the creation and enforcement of concepts such as private property (including now intellectual property), companies, stock markets, competition law, insurance, and so on. On the other hand, and at the same time, social, political and financial risk in capitalist societies creates new demands for regulation. ${ }^{23}$ Even over the last 30 years of deregulatory politics, regulation has grown and grown with rules and regulators set up in more and more countries to create competition, regulate newly privatised services such as telecommunications and rail, and address financial risks and social inequalities created by competition. As Drahos comments there seems to be "a regulatory version of Newton's third law: for every deregulatory or privatisation initiative, there was an opposite regulatory reaction from somewhere within the system." 24

The dominant liberal conception of regulation sees capitalism's impact on the natural world (the same as its impact on social inequality, financial system risk, and political crisis) as an "externality" or market failure. ${ }^{25}$ This approach to governance of environmental issues suggests the need for rules to fix market failures and address environmental harms one issue at a time. The rationale for regulation here is that markets create externalities including burdens on the environment and thus government, taxation and regulation are required to address these externalities in various ways. These include provision of

\footnotetext{
${ }^{20}$ See https://www.ellenmacarthurfoundation.org/circular-economy

${ }^{21}$ David Levi-Faur, "From "Big Government" to "Big Governance?"," in The Oxford Handbook of Governance, ed. David Levi-Faur (Oxford: Oxford University Press, 2012) at 289. 22 id.

23 id. See also David Levi-Faur, "The Global Diffusion of Regulatory Capitalism," The Annals of the American Academy of Political and Social Science 598 (2005).

${ }^{24}$ Drahos, "Regulating Capitalism's Processes of Destruction" at 763.

25 Robert Baldwin and Cave Martin, Understanding Regulation: Theory, Strategy and Practice (Oxford: Oxford University Press, 1999).
} 
environmental protection and remediation services by government (funded by taxation) and legal prohibitions and financial penalties or taxes in relation to specific environmental harms. We label this the instrumentally rational approach since regulation is designed to intrude as discretely and narrowly into (what is considered as inherently beneficial) business activity as possible.

An instrumentally rational approach does recognise the need for environmental regulation to address market failures. Indeed, there is a significant literature on environmental regulation and its successes and failures in a range of settings ${ }^{26}$ associated with different regulatory instruments and analysis of the conditions under which compliance is most likely to be forthcoming ${ }^{27}$.

Yet, when successfully implemented, environmental regulation is often criticised by proponents of instrumentally rational regulation as being in opposition to, or at least in tension with, the need to provide 'ideal' market conditions. Commitment to effective instrumental regulation is undermined by a discourse that supports markets, through the use of dominant and politically salient market 'scripts' 28 , that obscures and marginalises the need to reduce harm. Political expediency shapes how science is interpreted 29 and regulatory standards commensurably weak. Cap and trade initiatives - seen as an economically optimal method of dealing with 'externalities' - are characterised by weak pollution limits ('caps') where there is an over allocation of permits to pollute provided to affected businesses ${ }^{30}$. The discursive downplaying of effective regulation gains power through interaction with public choice perspectives which see governments as inherently constituted to increase their power and control. ${ }^{31}$ Hence, government regulation is itself seen as requiring strict control, ${ }^{32}$ with 'light touch' regulation, that intrudes as little as possible on the productive discipline of the market, preferred. ${ }^{33}$ At best, such regulation seeks to internalise responsibility for environmental externalities within the market through requiring compliance with rules, innovation and adoption of new technologies, environmental restoration and remediation, compensation and so on. Rarely, however, is outright prohibition of environmentally harmful conduct contemplated. Economic wealth and economic growth are seen as consistent with a reduction in

\footnotetext{
${ }^{26}$ Eg N Gunningham and P Grabosky, Smart Regulation: Designing Environmental Policy (Oxford: Clarendon Press, 1998); Neil Gunningham and Darren Sinclair, Leaders and Laggards: Next-Generation Environmental Regulation (Sheffield: Greenleaf Publishing, 2002); Neil Gunningham, Robert A. Kagan, and Dorothy Thornton, Shades of Green: Business, Regulation and Environment (Stanford, California: Stanford University Press, 2003); Aseem Prakash, Greening the Firm: The Politics of Corporate Environmentalism (Port Chester, NY: Cambridge University Press, 2000).

${ }^{27}$ Lesley McAllister, "Moving toward Stringency in Emissions Trading: The Problem of Slack Caps," Conference Papers -- Law \& Society (2008); David A. Evans and Joseph A. Kruger, "Taking up the Slack: Lessons from a Capand-Trade Program in Chicago," (Resources For the Future, Discussion Papers, 2006); Neil Gunningham, "Enforcing Environmental Regulation," Journal of Environmental Law 23, no. 2 (2011); Prakash, Greening the Firm: The Politics of Corporate Environmentalism, Søren C. Winter and Peter J. May, "Motivation for Compliance with Environmental Regulations," Journal of Policy Analysis and Management 20, no. 4 (2001); Stig S. Gezelius and Maria Hauck, "Toward a Theory of Compliance in State-Regulated Livelihoods: A Comparative Study of Compliance Motivations in Developed and Developing World Fisheries," Law \& Society Review 45, no. 2 (2011).

28 Ronald Chen and Jon Hanson, "The Illusion of Law: The Legitimating Scripts of Modern Policy and Corporate Law," Michigan Law Review 103, no. 1 (2004).

${ }^{29}$ Brian Wynne, "Uncertainty and Environmental Learning: Reconceiving Science and Policy in the Preventive Paradigm," Global Environmental Change 2, no. 2 (1992).

${ }^{30}$ McAllister, "Moving toward Stringency in Emissions Trading: The Problem of Slack Caps.", Stephen Smith and Joseph Swierzbinski, "Assessing the Performance of the Uk Emissions Trading Scheme," Environment and Resource Economics 37 (2007), Evans and Kruger, "Taking up the Slack: Lessons from a Cap-and-Trade Program in Chicago.", Robert Baldwin, "Regulation Lite: Emissions Trading," Regulation and Governance 2, no. 2 (2008).

31 For a critical review of public choice theory see Steven P. Croley, Regulation and Public Interests: The Possibility of Good Regulatory Government (Princeton University Press, 2008). pp. 284-303

32 Bronwen Morgan, "The Economisation of Politics: Meta-Regulation as a Form of Nonjuicial Legality," Social \& Legal Studies 12, no. 4 (2003).

33 Mathias Siems and Gerhard Schnyder, "Ordoliberal Lessons for Economic Stability: Different Kinds of Regulation, Not More Regulation," Governance 27, no. 3 (2014).
} 
environmental harm ${ }^{34}$ with the 'Environmental Kuznet's Curve'35 at play where initial increases in the environmental impact of extractive activity are followed by a progressive decline as wealth and technological sophistication increases.

The instrumentally rational approach to regulatory policy has a very visible impact on regulation through "reduction of "red tape" initiatives that periodically repeal or soften regulation, or make exemptions to fast track particular (often environmentally destructive), projects, in order to maintain conditions for investment and economic growth. Regulatory impact statements that include a cost benefit analysis and some form of 'cost to competition' calculation are favoured ${ }^{36}$ - thus privileging the need for competitive markets in the present over the needs of future generations in the assessment of what is needed to address environmental harms. ${ }^{37}$ Political contestation between market 'demands' and social pressure can result in lax environmental limits set alongside 'overly excessive' regulatory controls on the other ${ }^{38}$.

Ultimately, under an instrumentally rational approach, multiple, and sometimes competing regulatory regimes exist, ${ }^{39}$ each premised on the need to reduce a discrete harm by bringing it into the competitive equation. Yet regulatory regimes are not co-ordinated in their attempts to maximise the public benefit arising out of business activity. Each regime acts as a discrete initiative: for example, anti-trust is premised on the value of competitive markets, environmental regulation on reducing harm to the environment and occupational health and safety on worker health. Instrumentalism alone characterises regulation - even the state can be expendable. ${ }^{40}$ Regulation premised on the benefits of competition relies on individuals acting in their own interest to protect the environment, environmental responsibilities are translated into market opportunities e.g. green claims on products, green bonds, emission trading systems. ${ }^{41}$ This type of instrumentalism comes at a price - creative compliance or gaming of the system to avoid substantive change is one. ${ }^{42}$ Ritualism ${ }^{43}$ or meaningless compliance that also fails to achieve substantive change is another. A further limitation is capture of regulation to privilege larger economic operators who can afford to comply with environmental protection obligations over those of smaller economic operators whose competition may be eliminated due to their inability to afford compliance with environmental protection. ${ }^{44}$ Instrumentalism is also a product of a modernist, rationalist frame of reference that can fail to inspire. ${ }^{45}$

\footnotetext{
34 Peter Sephton and Janelle Mann, "Compelling Evidence of an Environmental Kuznets Curve in the United Kingdom," Environmental \& Resource Economics 64, no. 2 (2016).

35 for a critical analysis see Leigh Raymond, "Economic Growth as Environmental Policy? Reconsidering the Environmental Kuznets Curve," Journal of Public Policy 24, no. 3 (2004); Leo Dobes, Frank Jotzo, and David I. Stern, "The Economics of Global Climate Change: A Historical Literature Review," Jahrbuch Für Wirtschaftswissenschaften / Review of Economics 65, no. 3 (2014).

${ }^{36}$ Haines, The Paradox of Regulation: What Regulation Can Achieve and What It Cannot.

${ }^{37}$ See Ben J Richardson, Time and Environmental Law: Telling Nature's Time (Canbridge, UK: Cambridge University Press, 2017 [in press]).

${ }^{38}$ W. Kip Viscusi, "The Devaluation of Life," Regulation \& Governance 3, no. 2 (2009).

39 Fiona Haines and David Gurney, "The Shadows of the Law: Contemporary Approaches to Regulation and the Problem of Regulatory Conflict," Law \& Policy 25, no. 4 (2003).

40 J. Black, "Critical Reflections on Regulation," Australian Journal of Legal Philosophy (2002).

41 Christopher Wright and Daniel Nyberg, Climate Change, Capitalism, and Corporations: Processes of Creative SelfDestruction (Cambridge: Cambridge University Press, 2015).

42 Doreen McBarnet, "When Compliance Is Not the Solution but the Problem: From Changes in Law to Changes in Attitude," in Taxing Democracy: Understanding Tax Avoidance and Evasion, ed. Valerie Braithwaite (Aldershot, UK: Ashgate, 2003).

43 John Braithwaite, Toni Makkai, and Valerie A Braithwaite, Regulating Aged Care: Ritualism and the New Pyramid (Edward Elgar Publishing, 2007).

${ }_{44}$ As argued e.g. by B. Yundle, 'Bootleggers and Baptists in the theory of regulation', in: Levi-Faur, D. Handbook on the Politics of Regulation (Cheltenham: Edward Elgar, 2011) 25-32.

${ }^{45}$ Haines, The Paradox of Regulation: What Regulation Can Achieve and What It Cannot.
} 
Thus instrumental regulation cannot address the enormity of the problem we face. It is part of a system that has fundamentally inverted the relationship between (capitalist) economy and ecology. Instrumentally rational regulatory decision making privileges piecemeal instrumental thinking to address particular externalities at particular points in time yet systematically ignores cumulative, inter-related systemic problems. There is a need to reframe instrumental regulation's very understanding of the relationship between "market" and "environment" to comprehend that we and (and all our social and economic institutions) are embedded and interconnected in nature. It is no longer adequate to understand the market as dynamic, competitive and innovative with nature providing resources or creating boundaries external to the market. We must turn this inside out and recognise that the market is one phenomenon emergent from ecological and earth systems.

Regulatory capitalism - through instrumental regulation - has been very successful at incorporating and accommodating a diverse range of challenges and contests as to market failures and also switching to new technologies in response to changing material, economic and social circumstances. But now it is necessary and urgent to regulate the market place via the diversity of voices, life cycles and ecosystems that must be respected as planetary boundaries are rapidly transgressed. As Michel Callon points out, markets constantly seek to frame certain actors and relationships and considerations as relevant to particular transactions and exclude others; yet there are always relations that "defy framing" and it is impossible to eliminate all "overflow". ${ }^{46}$ Callon sees this as providing a normative opportunity to constantly listen to the voice and concerns of all actors and externalities impacted by markets, which will in turn reconfigure markets and our very ideas of political economy. ${ }^{47}$ We see this as the central challenge of "ecologically rational regulation" - to listen constantly to how we are interconnected with the earth community. Our concern here resonates with efforts to move towards ecological and post-capitalist approaches to economics, which seek to place markets within societies and ecologies rather than privileging the market and seeing society and environment as problems. ${ }^{48}$ The significance of regulatory studies is in seeking to understand how we move from here to there - how to encourage, influence or indeed force change, and with what expected and unexpected effects? As we shall argue below, responsively rational regulation picks up on this point, but may not take it far enough.

Second, instrumentally rational regulation's insistence on evidence-based regulatory policy making could also be reframed in a more ecologically rational mode as the need to prioritise methods for decision making based on listening to ecosystems. ${ }^{49}$ It also resonates with reflexive notions of science and science communication where scientific understandings of ecologies and earth systems are sensitive to indigenous and other heterodox knowledge systems to become transdisciplinary able to speak to the value of humans and environments. ${ }^{50}$ Can we radically expand the current need for regulation to be justified as against its impact on competition by now creating a discursive need to justify both business and regulatory activity against ecological impacts - as well as economic and social impacts?51 Several initiatives are worth noting here. Sjafjell's proposal that companies and their directors should have a legally enforceable duty to

\footnotetext{
46 Michel Callon, "Introduction: The Embeddedness of Economic Markets in Economics," in The Laws of the Markets, ed. Michel Callon (Oxford: Blackwell Publishers, 1998) at 17-18.

47 Id., p544.

${ }^{48}$ See Kate Raworth, Doughnut Economics: Seven Ways to Think Like a 21st Century Economist (White River Junction, Vermont: Chelsea Green, 2017); JK Gibson-Graham, Jenny Cameron, and Stephen Healy, Take Back the Economy, Environmental Education Research (Minneapolis: University of Minnesota Press, 2013).

${ }^{49}$ See Latour, Facing Gaia: Eight Lectures on the New Climatic Regime. (discussed further below); see also the call of Capra and Mattei, The Ecology of Law: Toward a Legal System in Tune with Nature and Community at 174-178 for law and governance to be based on "ecoliteracy".

${ }^{50}$ See eg John Paterson, "Trans-Science, Trans-Law and Proceduralization," Social \& Legal Studies 12, no. 4 (2003); Wynne, "Uncertainty and Environmental Learning: Reconceiving Science and Policy in the Preventive Paradigm.". ${ }^{51}$ There has recently been a suggestive attempt to do this with economics: Raworth, Doughnut Economics: Seven Ways to Think Like a 21st Century Economist, ibid.
} 
ensure business operates environmentally, socially and economically sustainably within planetary boundaries is promising. ${ }^{52}$ This must be more than merely a statement that directors should take stakeholder and environmental concerns into account in decision-making towards a radically transformational and all-encompassing form of "instrumental" regulation to ensure ecological survival. Such transformation may require a new crime of ecocide that would apply to business entities and governments at the national and international levels and outlaw defined by activists as "[T]he extensive destruction, damage to or loss of ecosystem(s) of a given territory, whether by human agency or by other causes, to such an extent that peaceful enjoyment by the inhabitants of that territory has been severely diminished." 53 Finally, a focus on the positive duty of cradle to grave extended producer liability is necessary. ${ }^{54}$ Where this is impossible (e.g. fossil fuels, tobacco) then some industries will need to transition out of their dominant business and to remedy and repair some of the damage they have caused. This would cause significant social dislocation, as many people depend on these entities for work and meaning and highlights the imperative to address social and economic as well as ecological impacts.

\section{Responsively Rational Regulation}

Regulatory capitalism theory observes that, despite capitalism's attempts to prioritise the market and competition over the social and political, the social and political constantly reassert themselves to reembed the market in social and political concerns. Regulation results from constant contests over the embedding and disembedding of the economic within the social, 55 or as Levi-Faur puts it, contests over commodification, decommodification and recommodification of social and environmental resources in capitalism. ${ }^{56}$ We might also see regulation as mediating the constant contest over the commons versus extractive capital. ${ }^{57}$

Responsively rational approaches to regulatory studies challenged and developed the instrumentally rational policy approach by emphasizing this interconnected nature of the social, political and economic alongside the empirical reality and normative desirability of iterated challenge, consultation and development of regulatory policy and business compliance. Responsively rational approaches see regulation as a plural "regulatory space" in which many different actors - from market, state and civil society sectors ${ }^{58}$ - engage in regulation of one another. It is not just a matter of the state regulating individuals and businesses, but

\footnotetext{
${ }^{52}$ Beate Sjafjell and Ben Richardson, eds., Company Law and Sustainability: Legal Barriers and Opportunities (Cambridge: Cambridge University Press, 2015). Note the need to ensure that such a proposal does not get watered down as occurred in the UK during the early 2000s see Eilís Ferran, "Company Law Reform in the United Kingdom: A Progress Report," Rabels Zeitschrift für ausländisches und internationales Privatrecht/The Rabel Journal of Comparative and International Private Law 69, no. 4 (2005) at p. 650.

${ }^{53}$ Fiona Haines and Christine Parker, "Moving Towards Ecological Regulation: The Role of Criminalisation," in Criminology and the Anthropocene, ed. Cameron Holley and Clifford Shearing (Routledge, In press); Polly Higgins, Damien Short, and Nigel South, "Protecting the Planet: A Proposal for a Law of Ecocide," Crime, Law and Social Change 59, no. 3 (2013); White and Kramer, "Critical Criminology and the Struggle against Climate Change Ecocide." ${ }^{54}$ We discuss the ecological scourge of plastics as an example briefly below: see World Economic Forum, "The New Plastics Economy: Rethinking the Future of Plastics," (World Economic Forum, 2016).

55 Bettina Lange, "Regulating Economic Activity through Performative Discourses: A Case Study of the Eu Carbon Market," in Regulatory Transformations: Rethinking Economy - Society Interactions, ed. Bettina Lange, Fiona Haines, and Dania Thomas (Oxford: Hart, 2015) following Karl Polanyi, The Great Transformation:(the Political and Economic Origin of Our Time) (Beacon Press, 1957).

${ }^{56}$ Levi-Faur, "Regulatory Capitalism."

${ }^{57}$ Capra and Mattei, The Ecology of Law: Toward a Legal System in Tune with Nature and Community.; Elinor Ostrom, Governing the Commons (Cambridge university press, 2015).

${ }^{58}$ Kenneth W. Abbott and Duncan Snidal, "Strengthening International Regulation through Transmittal New Governance: Overcoming the Orchestration Deficit," Vand. J. Transnat'l L. 42 (2009); John Braithwaite, "The New Regulatory State and the Transformation of Criminology," British J. of Criminology 40, no. 2 (2000); Neil Gunningham, Dorothy Thornton, and Robert A. Kagan, "Motivating Management: Corporate Compliance in Environmental Protection," Law \& Policy 27, (2005).
} 
of businesses regulating governments (e.g. a ratings agencies downgrades a government's credit rating), and civil society regulating business (a name and shame campaign against Nike for poor labour practices). Actors from each sector can be both regulatory and regulated at different times. Moreover the regulatory task can itself be divided into plural elements. Regulation is not just standard setting or rule making, but also the framing of the regulatory agenda and setting objectives; the implementation of rules within targets; the gathering of information and monitoring behaviour; responding to non-compliance via sanctions and other forms of enforcement; and evaluating policy and providing feedback, including review of rules. ${ }^{59}$ Different actors have different capacities to perform each of these different tasks in different times and contexts; and each has plural potential motivations and drivers for compliance - not merely short term financial self-interest, but also concern about social standing and commitment to particular values. Even inside business entities, regulatory agencies and governments there are different actors with different capacities and motivations.

Regulatory governance of any particular area at any particular time is thus the result of ongoing interactions (contests, conflicts, alliances, modelling and mimicry) between networks of multiple actors at multiple levels (local, national and global; and within and between agencies and organisations at each of these levels). This makes regulation highly responsive to a range of influences and motivating factors. New developments, facts and concerns can quickly prompt regulatory responses from networked civil society and government organisations (e.g. to protest sweatshop labour, promote divestment from fossil fuels or mandate technological innovation to overcome ozone depletion in the atmosphere). In the environmental context, Gunningham and his colleagues call for attention to social and economic 'licenses' alongside the 'legal licence' enshrined in regulatory regimes. They argue that the strength of business responses in going 'beyond compliance' depends on the strength of community scrutiny and its compatibility with what is considered a viable business strategy. ${ }^{60}$ It is also dependent on the degree to which business organisations and regulatory agencies can themselves be reflexive about their own activities. ${ }^{61}$ Parker and others have argued that it is possible or at least necessary to make businesses permeable to both state and civil society influence in a democratic society through requiring internal compliance systems, leveraging the agency of corporate insiders (e.g. environmental managers)who institutionalise social and environmental values inside the company, making it more responsive to stakeholders who contest corporate decisions and actions, and meta-regulation by the state of the company's internal responsibility systems to ensure accountability, responsibility and reflexion. ${ }^{62}$ Black and Baldwin have expanded this idea to call for regulatory agencies themselves to be responsive to range of risks and contexts and reflexively reconsider regulation in response. ${ }^{63}$ Yet the outcome is not necessarily predictable. The character of interaction and the capacities of the various actors interacting will determine whose interests or what values are ultimately reflected in any particular "regulatory space". ${ }^{64}$

Thus normatively-oriented responsively rational regulatory studies scholars propose that business, regulators and civil society organisations should be proactive, dynamic, responsive to multiple actors and

\footnotetext{
59 B. Eberlein et al., "Transnational Business Governance Interactions: Conceptualization and Framework for Analysis," Regulation and Governance 8, no. 1 (2014).

${ }^{60}$ Gunningham, Kagan, and Thornton, Shades of Green: Business, Regulation and Environment.

${ }^{61}$ Eg Eric W Orts, "Reflexive Environmental Law," Nw. UL Rev. 89 (1994).

${ }^{62}$ Christine Parker, The Open Corporation: Effective Self-Regulation and Democracy (Cambridge: Cambridge University Press, 2002).

${ }^{63}$ Julia Black and Robert Baldwin, "Really Responsive Risk-Based Regulation," Law \& Policy 32 (2010); Robert Baldwin and Julia Black, "Really Responsive Regulation," The Modern Law Review 71, no. 1 (2008).

${ }^{64}$ See Abbott and Snidal, "Strengthening International Regulation through Transmittal New Governance:

Overcoming the Orchestration Deficit" at 554-558.
} 
contexts, ${ }^{65}$ and organisational actors should responsively engage with external government and civil society organisations in order to internalise responsibility for regulatory goals. ${ }^{66}$ Ultimately, however, the conditions in which responsively rational regulation and regulatory studies are socially or indeed ecologically just are politically contingent - it depends on which voices are represented and heard. ${ }^{67}$ As scholars we can pay attention to noting this and trying to act to promote progressive politics of regulation - but ultimately this is a matter of a broader politics, not driven by regulation as such. Further scholars differ in their views of whose voices can and should drive reforms and the degree to which consensus or conflict and tension lie behind progressive change. ${ }^{68}$ Ultimately, there is no guarantee that responsively rational regulation (even in its most socially progressive form) will meaningfully recognise ecological embeddedness. ${ }^{69}$

Indeed, responsiveness is often shaped by economic and political interests and by a dominant orientation towards the market and competition as essentially positive. ${ }^{70}$ Responsive regulation policy proposals tend to assume the sort of deliberative democratic space that they are seeking to create - with ideas that are politically contingent on its existence. They require political action, active "sociological citizenship" by agents. ${ }^{71}$ Ultimately, regulatory institutions largely follow from political contestation rather than driving politics in a positive direction. Regulation is more often the means by which tensions between different risk pressures are managed, where governments are responding to political risk (threats to conditions for capital investment as well as threats to their legitimacy as 'protectors' of the citizenry) through regulatory reform. ${ }^{72}$ Governments in managing political risk often addresses socio cultural risk concerns (need for social meaning and preservation of community and social inclusion) only to the degree necessary to address political risk. Further, 'actuarial' risk demands (which include those posed by environmental degradation) are the most expendable. The way political risk concerns shape regulation means reform is often achieved through compromises that leave 'loopholes' or where the law is so complex that compliance is impossible - regulation is created to appear to deal with issues without actually changing very much. ${ }^{73}$

In short, responsively rational regulation does suggest how networks of plural actors can civilise capitalism through regulation both with and beyond government - but it does not provide a substantive

${ }^{65}$ Julia Black and Robert Baldwin, "Really Responsive Risk-Based Regulation," Law \& Policy 32 (2010); Robert Baldwin and Julia Black, "Really Responsive Regulation," The Modern Law Review 71, no. 1 (2008); Braithwaite, "The New Regulatory State and the Transformation of Criminology."

66 See Gunningham, Thornton, and Kagan, "Motivating Management: Corporate Compliance in Environmental Protection"; Parker, The Open Corporation: Effective Self-Regulation and Democracy; but see Christine Parker and Sharon Gilad, "Internal Corporate Compliance Management Systems," Explaining Compliance, Cheltenham, Edward Elgar (2011) for a critique of the potential of this work.

${ }^{67}$ Lange, "Regulating Economic Activity through Performative Discourses: A Case Study of the EU Carbon Market."

${ }^{68}$ Boaventura de Sousa Santos and Cesar A Rodrigues-Garavito, eds., Law and Globalization from Below: Towards a Cosmopolitan Legality, Cambridge Studies in Law and Society (Cambridge University Press, 2005).

${ }^{69}$ See Eric W. Orts and Alan Strudler, "The Ethical and Environmental Limits of Stakeholder Theory," Business Ethics Quarterly 12, no. 2 (2002).

70 McAllister, "Moving toward Stringency in Emissions Trading: The Problem of Slack Caps"; Lange, "Regulating Economic Activity through Performative Discourses: A Case Study of the EU Carbon Market"; Fiona Haines and Dylan McConnell, "Environmental Norms and Electricity Supply: An Analysis of Normative Change and Household Solar PV in Australia," Environmental Sociology 2, no. 2 (2016).

71 Susan S Silbey, "The Sociological Citizen: Pragmatic and Relational Regulation in Law and Organizations," Regulation \& Governance 5, no. 1 (2011).

72 Haines, The Paradox of Regulation: What Regulation Can Achieve and What It Cannot.

${ }^{73}$ Nils Brunsson, The Organization of Hypocrisy, trans. Nancy Adler, Second ed. (Abstrakt: Copenhagen Business School Press, 2002), Haines, The Paradox of Regulation: What Regulation Can Achieve and What It Cannot. See also Bronwen Morgan, "Upside Down and inside Out," in The Handbook of Law and Society (John Wiley \& Sons, Inc, 2015). 
pathway for the substantial and radical need to recognise the embeddedness of all of human activity including governance institutions and markets in the ecological. Although responsively rational regulation demonstrates that plural voices can in fact impact on regulating capitalism ${ }^{74}$ and normatively proposes responsive procedures for these voices, we are only just beginning to develop ways - in scholarship and policy - to listen to ecology itself. Ecology lacks voice in regulation. Responsively rational regulation tends to assume some civil society actors will stand up for environmental values, ${ }^{75}$ yet we must now conceptualise the ecology or biosphere or Gaia as an actor in its own right and one in which we are all embedded and interconnected. ${ }^{76}$

This raises a second problem - that responsive regulation tends to be procedural and not political in orientation. We have begun to notice that challenges of regulation are fundamentally political. But we have not yet begun to come to terms with the real ontological and existential challenge we face with ecological regulation. So even when ecology has a voice, it becomes one stakeholder among others. We have not yet realised that planetary boundaries must and do - one way or another - both ground and trump all social and economic concerns.

\section{AN AGENDA FOR ECOLOGICALLY RATIONAL REGULATION}

Two distinct aspects to the ecological regulation agenda emerge from the discussion above. The first is to draw attention to regulation that is consistent with maintaining human life within the safe operating space for humanity and conversely to regulations that are most harmful in this respect. The second follows on from this -to identify the characteristics of regulation consistent with preservation of ecological goals and to ask whether they have distinct 'ecological' characteristics.

The first of these elements focuses on outcomes and so raises the thorny challenge of how to recognize ecological limits. A full exploration of this is beyond the limits of the paper. Nonetheless, we would argue, consistent with the above, that instrumentally rational regulation can help in pointing to the importance of scientific evidence in assisting with this question. To be sure, philosophers of science as well as STS scholars would point to the fallibility of science (a view shared by scientific epistemology itself ${ }^{77}$ ) and its uptake as politically contingent. Our analysis above also cautions against an uncritical stance towards scientific knowledge. Yet, to argue that fallibility and the political challenges associated with scientific knowledge discredits it entirely is not tenable. This strategy provides considerable support to those with an economic and political interest in maintaining our current ecologically destructive path. ${ }^{78}$ Further, scientific epistemologies are not unitary. Attention to debates and conflicts within science about how to understand when new scientific insight has been gained is important, for example in debates between hypothetico-deductive and inductive modalities ${ }^{79}$. Different people involved in understanding ecological limits outside of academe are important, including citizen science ${ }^{80}$. So, too, is attention to how ecologies 'speak'. This is not necessarily esoteric - 'clean up' campaigns point to the increasing impact of plastic pollution just as farmers can highlight the changing pattern of seasons. In some cases, listening does not

\footnotetext{
${ }^{74}$ In tune with Callon's observation noted above at text accompanying note 46.

75 See Stone, Should Trees Have Standing? Law, Morality and the Environment.

${ }^{76}$ Latour, Facing Gaia: Eight Lectures on the New Climatic Regime.

${ }_{77}$ Nicholas Tilley, "Popper, Positivism and Ethnomethodology," The British Journal of Sociology 31, no. 1 (1980); Jan Beyea and Daniel Berger, "Scientific Misconceptions among Daubert Gatekeepers: The Need for Reform of Expert Review Procedures," Law and Contemporary Problems 64, No. $2 \& 3$ (2001).

${ }^{78}$ Latour makes this point powerfully in Latour, Facing Gaia: Eight Lectures on the New Climatic Regime.

${ }^{79}$ In the context of ecology see Michael T. Mentis, "Hypothetico-Deductive and Inductive Approaches in Ecology," Functional Ecology 2, no. 1 (1988).

${ }^{80}$ Fiona Haines, "Vanquishing the Enemy or Civilizing the Neighbour? Controlling the Risks from Hazardous Industries," Social \& Legal Studies 18, no. 3 (2009).
} 
require a particular acuity - it might be readily apparent. What is challenging is to increase the political salience of such knowledge, from whatever source, and how it can be included in the regulatory process.

A related challenge is in understanding how regulatory frameworks assist, or inhibit listening. Here the focus shifts from the first element of assessing outcomes to the second of attending to the characteristics of ecologically rational regulation. We sketch out below some preliminary thoughts about this challenge, taking our cue from our analysis of the limits of both instrumentally and responsively rational regulation:

\section{Avoiding the Perpetuation of Monocultures}

Our first impulse in mapping what an ecologically rational approach to regulation might look like was to begin by using an example such as the crisis arising out of the overproduction and overconsumption of plastics. Plastics will constitute $50 \%$ of the mass of the ocean (the same as fish) by 2050 under a business as usual scenario. There is much important and pertinent work being done on the regulatory challenge of plastics, most prominently by the Ellen Macarthur Foundation. ${ }^{81}$ But, we soon realised that this analysis risks reinscribing the very crises we are trying to avert. There are three primary reasons for this. Firstly, a focus on one particular problem risks losing focus on the interconnectedness of ecological challenges repeating the inherent problems in an instrumental approach to regulation. For example, the shift to the production of plastic from oil-based to plant-based sources might generate critical food shortages by displacement of plants for human consumption towards those used in the 'ecologically sustainable' production of plastic. Secondly, a focus on how regulation should occur glosses over the political, social and economic challenges that will be faced in ensuring it does occur. Finally, a focus on regulation of a particular product may fail to interrogate the connection between capitalist production and the development of what might be termed 'monocultural' solutions to human problems more generally. The ecological challenge we face comes from an over-reliance on monocultures and a radical loss of diversity, not only diversity in species loss, but also in many other things such as sources and kinds of food. ${ }^{82}$ Mapping out a shift to ecological regulation requires questioning regulation's role to date in creating monoculture.

Plastics are a particularly interesting example. To focus on one particular use, plastics have become the ubiquitous and default 'monocultural' means for preserving and transporting consumer goods. Plastic has significant advantages, as all monocultures do, ${ }^{83}$ and some of these advantages have been supported by regulation. These include preserving the life of food, decreasing contamination and easing the challenge of transportation. However, plastics have also displaced a plethora of alternative forms of packaging as well as alternative forms of transportation. Plastic has replaced organic materials, such as paper and banana leaves, as well as labour in the transportation process. It has changed the nature of social interactions in the shift towards takeaway food. Understood as a monoculture, plastic has colonised and restructured social and economic relationships. Significant benefits have come at an ecologically unsustainable cost, a cost we are only now beginning to face.

We believe the starting point for ecological regulation, then, is not to engage with a particular 'monoculture' such as plastic and how it might be better managed. It is rather to look for new configurations of economic and social arrangements that can better solve critical ecological challenges in diverse ways. To some degree, this builds on a nascent regulatory literature that draws on and reframes responsive regulation looking to diverse forms of empowerment that challenge dominant economic and

\footnotetext{
81 World Economic Forum, Ellen MacArthur Foundation, and McKinsey and Company, "The New Plastics Economy: Rethinking the Future of Plastics," ed. Ellen MacArthur Foundation (2016).

82 See IPES-Food, "From Uniformity to Diversity: A Paradigm Shift from Indistrial Agriculture to Diversified

Agroecological Systems," (International Panel of Experts on Sustainable Food Systems, 2016).

83 See Anthony L. Andrady and Mike A. Neal, "Applications and Societal Benefits of Plastics," 2009.
} 
political regimes and reshape regulation and governance itself. ${ }^{84}$ In looking to diversity, we need to go beyond the problem of "illustrative examples" or interesting case studies to build a solid understanding of the multiple interacting pathways by which ecological regulation would support ecological sustainability and resilience.

\section{Promoting Diversification}

There are already a multiplicity of literatures, practices and related debates aimed at tackling the ecological crises we face that range from ecological economics to sustainable development. What can an ecologically rational regulatory studies approach add? As indicated above, some of the building blocks for ecological regulation can be sourced from both instrumentally and responsively rational forms of regulation. From the instrumentaly rational regulatory approach we would explore competition as a potentially important element to reframe. ${ }^{85}$ Arguably, the key to ecological resilience is to ensure a diversity of ways that socially embedded forms of economic exchange can take place and with it a diversity of regulatory approaches. ${ }^{86}$ Instrumentally rational regulation has privileged a particular form of competition rather than competition to promote a diversity of competing forms of ecological sustainability in production, consumption, and exchange relationships. Earlier versions of competition law promoted diversity among businesses as a significant protection against political, social and economic domination by businesses that would otherwise grow too large and powerful. ${ }^{87}$ We now need to encourage ongoing innovation and small scale economic activity that meets real human and social needs within planetary boundaries. ${ }^{88}$ Ecologically rational regulation should support a diversity of business activities that operate within planetary boundaries and compete with and challenge business activity that does not!

The size and scope of the ecological challenges require us to go beyond a focus on local, boutique forms of economic and social exchange. This is not to criticise the value of what is being achieved in local areas for the wellbeing of particular communities and local ecologies. But the job of ecologically rational regulatory studies should be to find and analyse ways that these new potentially ecologically sustainable forms interact with and challenge dominant regulatory frameworks, frameworks that form the familiar terrain for major global capitalist enterprises. The local cannot just exist in market niches - but must challenge globally dominant ${ }^{89}$ enterprises to change their modus operandi or cease to exist. A regulatory analysis of how regulations support or undermine diversity can reveal the connections between local and dominant socio-economic forms.

The need for this top down perspective can usefully draw from the responsively rational regulatory scholarship to deepen understanding of expanded networks of actors who regulate. Beyond civil society, plants, animals, trees, oceans, microbes and so on also 'regulate' and respond to human behaviour in the sense that they influence our behaviour. ${ }^{90}$ In both cases, civil society and 'nature' can regulate with both

\footnotetext{
${ }^{84}$ de Sousa Santos and Rodrigues-Garavito, eds., Law and Globalization from Below: Towards a Cosmopolitan Legality.; Morgan, "Upside Down and inside Out.".

85 See eg David M Driesen, The Economic Dynamics of Environmental Law (MIT press, 2003).

86 See Gibson-Graham, Cameron, and Healy, Take Back the Economy.

${ }^{87}$ See Tony Freyer, Antitrust and Global Capitalism, 1930-2004 (Cambridge: Cambridge University Press, 2006).

${ }^{88}$ See for example Amy J Cohen, "The Law and Political Economy of Contemporary Food: Some Reflections on the Local and the Small," Law \& Contemp. Probs. 78 (2015).

89 These dominant industries include both privately owned and state owned enterprises that thrive on international trade see Richard Heede, "Tracing Anthropogenic Carbon Dioxide and Methane Emissions to Fossil Fuel and Cement Producers, 1854-2010," Climatic Change 122, no. 1 (2014).

90 Latour, Facing Gaia: Eight Lectures on the New Climatic Regime.
} 
positive and negative consequences. ${ }^{91}$ In the absence of strong regulatory boundaries to protect ecological limits species decline and global climatic change will accelerate, but there will be a non-human response as diseases may thrive in hitherto inaccessible populations ${ }^{92}$ and certain species proliferate (cockroaches, jellyfish). Legal controls - or their lack intersect with ecological change. In a very real sense 'nature regulates'. ${ }^{93}$

Ecological regulation will therefore face quite an agenda. We suggest there are three key questions that ecological regulation should ask of new ecologically sustainable initiatives:

- The degree to which they allow solutions to intersecting ecological sustainability and social wellbeing challenges. Ecological regulation must encourage initiatives that seek to solve diverse, interconnected problems. They cannot be instrumental and piecemeal. In doing so ecologically rational regulation must listen to and allow regulation by diverse human and non-human actors and ultimately earth systems themselves. The ecologically rational result may be regulation that takes the form of 'messy' political 'deals' that focus on multiple forms of environmental damage rather than instrumental 'rules' that target only one such problem. ${ }^{94}$ Rather ecologically rational regulatory institutions will have to connect different substantive policy goals or problems. Beyond the networks of actors envisaged by responsive regulation, we must look at networks of issues.

- The degree to which ecologically sustainable initiatives simply remain 'tolerated' as niche markets ${ }^{95}$ with limited overall impact or whether they encourage or challenge dominant forms of production and consumption to change in more ecologically sustainable ways (e.g. towards circular production systems). Competition and contestation are important for generating diversity, dynamism and resilience, rather than locking in point in time environmental solutions to particular problems. Ecologically rational regulation should not simply replace one monoculture with another. Ecologically resonant competition is premised on the need for ongoing generative diversity not merely 'survival of the fittest' monoculture.

- The need to be alert to the potentially perverse consequences that may arise in developing new initiatives e.g. reinscribing inequality and possibility generating new dimensions to that inequality. Environmental initiatives directed at the already privileged have often added to inequality exacerbating environmental racism ${ }^{96}$. But there is the possibility of new dimensions added to such inequality. For example, the shift towards renewable, distributed energy require increased technical skills of solar or wind generating households and communities in order to manage what was previously a centrally provided resource. Inequalities in wealth (i.e. the wealthy have easier access to generating their own electricity) can be exacerbated by inequalities in skills (i.e. maintaining distributed systems requires skills that are themselves unequally distributed).

91 Ibid; Scott Burris, Ichiro Kawachi, and Austin Sarat, "Integrating Law and Social Epidemiology," The Journal of Law, Medicine \& Ethics 30, no. 4 (2002); Scott Burris, "Law as a Structural Factor in the Spread of Communicable Disease," Hous. L. Rev. 36 (1999); Scott Burris, Peter Drahos, and Clifford Shearing, "Nodal Governance," Australian Journal of Legal Philosophy 30 (2005).

92 Burris, "Law as a Structural Factor in the Spread of Communicable Disease."

${ }^{93}$ See Clive Hamilton, Defiant Earth: The Fate of Humans in the Anthopocene (Crows Nest, NSW: Allen and Unwin, 2017); Latour, Facing Gaia: Eight Lectures on the New Climatic Regime.

94 Morgan, "Upside Down and inside Out."

95 As has been a criticism of various existing 'fair trade', sustainability and animal welfare regimes. See T. Bartley et al., Looking Behind the Label: Global Industries and the Conscientious Consumer (Indiana University Press, 2015). Christine Parker, "Voting with Your Fork? Industrial Free-Range Eggs and the Regulatory Construction of Consumer Choice," The Annals of the American Academy of Political and Social Science 649, no. 1 (2013).

${ }^{96}$ For a review and reflection in the context of Nigeria see Wilson Akpan, "Between Ethnic Essentialism and Environmental Racism: Oil and the 'Glocalisation' of Environmental Justice Discourse in Nigeria," African Sociological Review / Revue Africaine de Sociologie 10, no. 2 (2006). 
The danger is a new form of 'responsibilisation' in which individuals are told they must take responsibility for ecological as well as social and economic wellbeing, an approach that distracts attention from the need for collective and systemic solutions. ${ }^{97}$

\section{CONCLUSION}

We have argued that currently regulation, in practice and study, is shaped by economic and social drivers, where regulatory outcomes emerge from political contestation between the two. The ecological is the larger, overarching driver in which economic, social and political understanding of regulation must be placed. Yet, the ecological is often crucially absent from the practice and study of regulation. The dominant instrumentally rational understanding of the purpose of regulation is problem focussed, fixing market 'externalities'. Further, the problem with such regulation is conceived in terms of its negative consequences for competition rather than its inability to ensure ecological limits are respected. Alternative socio-legal perspectives on regulation are responsively rational. They note that business activity, markets and capitalism itself is permeable and responsive to plural influences and pressures. This offers some promise for dynamically and proactively addressing environmental issues. But such responsiveness is politically contingent, with political dynamics often favouring particular social agendas and economic interests. To date, responsive regulation has not sufficiently addressed the larger ecological challenge despite the reality that earth systems encompass and connect us all. Responsively rational regulation is not yet responsive enough to ecological voice.

Ecologically rational regulation is explicitly orientated towards providing regulatory tools that can engender ecologically sustainable and socially just communities. Ecologically rational regulatory studies would build on elements from both instrumentally and responsively rational regulation, in particular the value of contestation and competition from the former and the need for dynamic social responsiveness to diverse networks of actors from the latter. Our suggested approach is not alone in arguing for strong limits to be placed on ecologically damaging activity but an ecologically rational approach also turns attention to the need to both listen to earth systems through science and other knowledge systems; and understand how multiple, diverse ways of sustainable being can intersect with and challenge current regulatory regimes dominated by an instrumentally rational approach. We suggest that ecological regulation would support convergence, contestation and competition between diverse sustainable futures. It takes seriously the lessons from ecology that diverse competing systems can generate overall sustainability, rather than insistence that a single philosophy or set of norms are needed to engender an ecologically sustainable and socially just future.

97 Haines and McConnell, "Environmental Norms and Electricity Supply: An Analysis of Normative Change and Household Solar PV in Australia." 


\section{University Library}

\section{- M M I N E R VA A gateway to Melbourne's research publications}

Minerva Access is the Institutional Repository of The University of Melbourne

Author/s:

Parker, C; Haines, F

Title:

An Ecological Approach to Regulatory Studies?

Date:

2018

Citation:

Parker, C. \& Haines, F. (2018). An Ecological Approach to Regulatory Studies?. Journal of Law and Society, 45 (1), pp.136-155. https://doi.org/10.1111/jols.12083.

Persistent Link:

http://hdl.handle.net/11343/295815 